\title{
KARAKTERISTIK PETANI BERLAHAN SEMPIT DI DESA TOLOK KECAMATAN TOMPASO
}

\author{
Miranda Mandang \\ Mex Frans Lodwyk Sondakh \\ Olly Esry Harryani Laoh
}

\begin{tabular}{ll}
\hline Naskah diterima melalui Website Jurnal Ilmiah agrisosioekonomi@unsrat.ac.id & : Kamis, 09 Januari 2020 \\
Disetujui diterbitkan & :Sabtu, 11 Januari 2020 \\
\hline
\end{tabular}

\begin{abstract}
This study aims to determine the characteristics of smallholder farmers in Tolok Village, Tompaso District. The study was conducted in August to September 2019. The selection of samples in this study was carried out purposevley with 33 respondent farmers, namely those who have small size of land of less than 0.5 hectares. The data used in this study are primary data and secondary data. Primary data collected through interviews and observations. Secondary data were obtained from the Tolok Village office, library and the Internet. Data analysis uses description analysis, which describes the characteristics of smallholder farmers and is presented in tabular form. The results showed that farmers who have small size of land with low income and are unable to rely solely on the agricultural sector as a source of income. The non-agricultural sector is also used as a source of additional income to meet their needs. ${ }^{*}{ }^{*}$ rm ${ }^{*}$
\end{abstract}

Keywords: small holder farmers, characteristics, small size of land, Tolok Village

\begin{abstract}
ABSTRAK
Penelitian ini bertujuan untuk mengetahui karakteristik petani berlahan sempit di Desa Tolok Kecamatan Tompaso. Penelitian dilaksanakan pada bulan Agustus sampai September 2019. Pemilihan sampel dalam penelitian ini dilakukan secara sengaja dengan jumlah petani responden sebanyak 33, yaitu mereka yang memiliki lahan sempit yang kurang dari 0,5 hektar. Data yang digunakan dalam penelitian ini adalah data primer dan data sekunder. Pengumpulan data primer melalusi wawancara dan observasi. Data sekunder diperoleh dari Kantor Desa Tolok, perpustakaan dan Internet. Analisis data menggunakan analisis deskripsi, yaitu mendeskripsikan karakteristik petani berlahan sempit dan disajikan dalam bentuk tabel. Hasil penelitian menunjukkan bahwa petani yang memiliki lahan sempit dengan pendapatan yang rendah dan tidak mampu hanya mengandalkan sektor pertanian sebagai sumber pendapatan. Sektor non-pertanian juga dijadikan sumber pendapatan tambahan untuk memenuhi kebutuhan. ${ }^{*}$ eprm*
\end{abstract}

Kata kunci : luas lahan,karakteristik petani, lahan sempit, Desa Tolok 


\section{PENDAHULUAN}

Pertanian merupakan salah satu sektor utama yang menopang kehidupan masyarakat karena sektor pertanian menjadi mata pencaharian sebagian besar penduduk Indonesia. Banyaknya rumah tangga yang menggantugkan diri pada sektor pertanian membuat sektor pertanian berperan penting dalam perekonomian nasional. Tetapi hal ini belum membuat sektor pertanian menjadi mapan.

Tantangan pembangunan pertanian di Indonesia dalam menghadapi era agribisnis adalah adanya kenyataan bahwa pertanian di Indonesia masih didominasi oleh usaha tani kecil yang dilaksanakan oleh berjuta-juta petani yang sebagian besar tingkat pendidikannya rendah, berlahan sempit, bermodal kecil dan memiliki produktifitas yang rendah.

Produksi pertanian dipengaruhi oleh faktor produksi diantaranya yaitu lahan, tenaga kerja, modal dan kemampuan manajemen. Lahan pertanian merupakan penentu dari pengaruh bagi faktor produksi komoditas pertanian. Secara umum dapat dikatakan bahwa semakin luas lahan yang ditanami maka akan semakin besar produksi yang dihasilkan dari lahan tersebut (Rahim dan Hastuti, 2007).

Kondisi petani di Desa Tolok memiliki lahan yang relative sempit. Kemungkinan pengembangan pada lahan sempit sebenarnya masih mempunyai peluang yang cukup besar seandainya lahan tersebut dapat dimanfaatkan secara optimal dan intensif. Pemanfaatan yang berupa penanaman dengan jenis tanaman yang memiliki nilai jual tinggi. Kepemilikan lahan pertanian di Desa Tolok, tidaklah sama diantara masing-masing petani. Data pemilikkan lahan pertanian di Desa Tolok dapat dilihat pada Tabel 1.

\begin{tabular}{|c|c|c|}
\hline No. & Pemilikan Lahan Pertanian & Keluarga \\
\hline 1. & Tidak Memiliki Lahan & 67 \\
\hline 2. & $\begin{array}{l}\text { Jumlah Keluarga Petani yang } \\
\text { Memiliki Lahan Sempit }\end{array}$ & 64 \\
\hline 3. & Memilki > 1 ha & 60 \\
\hline & Jumlah & 191 \\
\hline
\end{tabular}

Tabel 1 menunjukkan bahwa dari jumlah keluarga petani yaitu 191 petani, hanya 60 keluarga yang memiliki lahan pertanian lebih dari $1 \mathrm{Ha}$, keluarga petani yang memiliki tanah pertanian sempit dibawah 1 ha yaitu dengan jumlah 64 petani, kemudian keluarga petani yang tidak memiliki lahan sendiri dengan jumlah 67 petani. Adapaun data data pengusahaan lahan pertanian Desa Tolok dapat dilihat pada Tabel 2.

Tabel 2. Data Pengusahaan Lahan Pertanian Desa Tolok

\begin{tabular}{clc}
\hline No. & \multicolumn{1}{c}{ Jenis Tanaman } & $\begin{array}{c}\text { Jumlah } \\
\text { Pengusahaan } \\
\text { Lahan Pertanian }\end{array}$ \\
\hline 1. & Jagung & 84 \\
2. & Padi & 78 \\
3. & Lainnya (Kacang Tanah, Tomat) & 29 \\
\hline \multicolumn{2}{l}{ Sumber : Kantor Desa Tolok Kecamatan Tompaso }
\end{tabular}

Sumber : Kantor Desa Tolok Kecamatan Tompaso

Tabel 2 menunjukkan pengusahaan lahan yang ada di Desa Tolok, dimana lebih banyak mengusahakan jagung dan padi, pengusahaan jagung sebanyak 84 petani selanjutnya pengusahaan padi 78 petani, dan lainnya Kacang Tanah, Tomat, Cabai, dan labu memiliki jumlah 29 petani.

\section{Lahan Sempit}

Lahan pertanian merupakan penentu dari pengaruh komoditas pertanian. Secara umum dikatakan, semakin luas lahan ditanami maka semakin besar jumlah produksi yang dihasilkan oleh lahan tersebut. Ukuran lahan pertanian dapat dinyatakan dengan hektar (ha).

Penyebab utama kemiskinan penduduk perdesaan yang sebagian besar berpenghasilan utama sebagai petani adalah karena sebagian besar petani tergolong petani kecil dengan rata-rata luas penguasaan lahan kurang dari 0,5 hektar. Di Indonesia, definisi petani kecil lebih sering mengacu pada luas lahan usahatani. Sajogyo (1977) mengelompokkan petani ke dalam tiga kategori, yaitu: petani skala kecil dengan luas lahan usahatani $<0,5$ ha, skala menengah dengan luas lahan usahatani $0,5-1,0$ ha, dan skala luas dengan luas lahan usahatani $>1,0$ ha.

Menurut pemahaman umum, usahatani pada lahan sempit kurang efisien sehingga secara umum lebih disukai usahatani dengan skala luas. Namun dari beberapa hasil kajian menyimpulkan bahwa usahatani skala kecil pada dasarnya tidak lebih buruk dibandingkan usahatani skala luas, paling tidak memiliki efisiensi produksi yang sama.

\section{Karakteristik Petani Kecil}

Definisi petani kecil (pertanian skala kecil) yang selama ini digunakan sebagai acuan secara umum didasarkan pada luas lahan usahatani yang dimiliki atau dikelola (Von Braun, 2004). Petani memiliki konotasi dan atribut yang berbeda, peasant dan farmer. 
Secara mudahnya, peasant adalah gambaran dari petani yang subsisten, sedangkan farmer adalah petani modern yang berusahatani dengan menerapkan teknologi modern serta memiliki jiwa bisnis yang sesuai dengan tuntutan agribisnis. Peasant adalah suatu kelas petani yang merupakan petani kecil, penyewa (tenants), penyakap (sharecroppers), dan buruh tani. Petani peasant Memiliki lahan pertanian yang sempit serta modal yang relatif kecil, yang melekat pada peasant adalah sikap kerjasamanya satu sama lain, usahatani kecil, dan menggunakan tenaga keluarga sendiri.

Peasant Mempunyai sumberdaya terbatas sehingga menciptakan tingkat hidup yang rendah, bergantung seluruhnya atau sebagian kepada produksi yang subsisten. Petani farmer berusahatani dengan bantuan tenaga buruh tani dan bertujuan mencari keuntungan.

Petani farmer menggunakan peralatan pertanian yang modern, bersifat Profit Oriented artinya selain dipergunakan untuk kebutuhan sehari-hari, sebagian besar hasil pertaniannya dijual ke pasar. Jadi tipe petani sangat berorientasi ekonomi yaitu untuk mendapatkan keuntungan lebih.

\section{Karakteristik Petani Berlahan Sempit}

Karakteristik individu adalah ciri-ciri atau sifat-sifat yang dimiliki oleh seseorang petani yang ditampilkan melalui pola pikir, pola sikap dan pola tindakan terhadap lingkungan. Ciri-ciri atau sifat-sifat yang dimiliki oleh petani meliputi beberapa factor atau unsur-unsur yang melekat pada diri seseorang dapat dikatakan sebagai karakteristik petani.

Karakteristik yang diamati dalam penelitian ini adalah umur, pendidikan, pengalaman berusaha tani dan jumlah tanggungan petani

\section{Umur}

Menurut Soekartawi (2003), rata rata petani Indonesia yang cenderung tua dan sangat berpengaruh pada produktivitas sektor pertanian Indonesia Petani berusia tua biasanya cenderung sangat konservatif (memelihara) menyikapi perubahan terhadap inovasi teknologi. Berbeda halnya dengan petani yang berusia muda.

\section{Pendidikan}

Menurut Hasyim (2003), tingkat pendidikan formal yang dimiliki petani akan menunjukkan tingkat pengetahuan serta wawasan yang luas untuk petani menerapkan apa yang diperolehnya untuk peningkatan usahataninya.

3. Lama berusahatani

Menurut Soekartawi (2003), pengalaman seseorang dalam berusahatani berpengaruh dalam menerima inovasi dari luar. Petani yang sudah lama bertani akan lebih mudah menerapkan inovasi dari pada petani pemula atau petani baru.

4. Jumlah tanggungan

Menurut Hasyim (2003), jumlah tanggungan keluarga adalah salah satu faktor yang perlu diperhatikan dalam menentukan pendapatan dalam memenuhi kebutuhannya. Banyaknya jumlah tanggungan keluarga akan mendorong petani untuk melakukan banyak aktivitas terutama dalam mencari dan menambah pendapatan keluarganya. Semakin banyak anggota keluarga akan semakin besar pula beban hidup yang akan ditanggung atau harus dipenuhi. Jumlah anggota keluarga akan mempengaruhi keputusan petani dalam berusahatani (Soekartawi, 2003).

5. Luas Lahan Usaha tani

Lahan merupakan sarana produksi bagi usaha tani, termasuk salah satu faktor produksi dan pabrik hasil pertanian. Lahan adalah sumberdaya alam fisik yang mempunyai peranan sangat penting bagi petani.

6. Kompetensi

Kompetensi merupakan kemampuan untuk melaksanakan tugas-tugas secara efektif dan merupakan refleksi dari kinerja yang dilakukan seseorang dalam menyelesaikan tugas dan pekerjaannya.

\section{Usaha Tani}

Ilmu usaha tani merupakan ilmu yang mempelajari cara-cara petani menentukan, mengorganisasikan penggunaan faktor-faktor produktif seefektif dan seefisien mungkin sehingga usaha tersebut memberikan pendapatan semaksimal mungkin.

Usahatani adalah suatu tempat dimana seseorang atau sekumpulan orang berusaha mengelola unsur-unsur produksi seperti alam, tenaga kerja, modal dan ketrampilan dengan tujuan

Agrisosioekonomi: 
berproduksi untuk menghasilkan sesuatu di lapangan pertanian. Sehingga dapat disimpulkan bahwa usaha tani adalah kegiatan pertanian dalam pengelolaan sumber daya alam, tenaga kerja, manajemen, permodalan dan lainnya untuk menghasilkan pendapatan yang dapat menjadikan kesejahteraan bagi petani dan memperbaiki taraf hidup petani.

\section{Unsur-unsur Usahatani}

Produktivitas usahatani semakin tinggi bila petani atau produsen mengalokasian faktor produksi berdasarkan prinsip efisiensi teknis dan efisiensi harga. Faktor produksi dalam usahatani memiliki kemampuan terbatas untuk berproduksi secara berkelanjutan, tetapi dapat ditingkatkan nilai produktivitasnya melalui pengelolaan yang tepat, misalnya faktor produksi lahan. Berikut uraian dari masing-masing faktor produksi dalam usahatani.

1. Tanah

A. Sumber pemilikan tanah dapat diperoleh dari beberapa sumber, antara lain:

a. Beli: Tanah yang dibeli merupakan tanah milik yang memilki ketentuan misalnya dibuktikan dengan bukti kepemilikan yaitu sertifikat yang dikeluarkan oleh negara melalui Kantor Pertanahan Nasional.

b. Sewa

c. Sakap : Menggarap tanah atas dasar bagi hasil

d. Warisan : Tanah yang karena hukum agama dibagikan kepada ahli warisnya

e. Wakaf : Tanah yang diberikan atas seseorang atau badan kepada pihak lain (misalnya untuk kegiatan sosial).

B. Status tanah

a. Tanah Hak Milik

Tanah milik memiliki ciri-ciri sebagai berikut:

1) Bebas diolah oleh petani

2) Bebas untuk merencanakan dan menentukan cabang usaha di atas tanah tersebut

3) Bebas menggunakan teknik dan cara budidaya yang paling dikuasai dan disenangi oleh petani

4) Bebas di perjualbelikan

5) Dapat menumbuhkan menurut tanggungjawab atas tanah tersebut

6) Dapat dijaminkan sebagai agunan

b. Tanah Sewa
Tanah Sewa adalah tanah yang disewa oleh petani kepada pihak lain.

c. Tanah Sakap

Tanah sakap adalah tanah orang lain yang atas persetujuan pemiliknya, digarap atau dikelola oleh pihak lain. Pengelolaan usahataninya, seperti penentuan cabang usaha dan pilihan teknologi harus dikonsultasikan dengan pemiliknya.

\section{d. Tanah Gadai}

Tanah gadai adalah pengalihan penguasaan hak garap tanah dari pemilik tanah kepada pemilik uang.

e. Tanah Pinjaman

2. Tenaga Kerja

Tenaga kerja adalah energi yang dicurahkan dalam suatu proses kegiatan untuk menghasilkan suatu produk. Tenaga kerja manusia (laki-laki, perempuan dan anak anak) bisa berasal dari dalam maupun luar keluarga.

Petani adalah setiap orang yang melakukan usaha untuk memenuhi sebagian atau seluruh kebutuhan hidupnya di bidang pertanian dalam arti luas yang meliputi usahatani pertanian, peternakan, perikanan dan pemungutan hasil laut.

Petani memiliki banyak fungsi dan kedudukan atas perannya, antara lain

a. Petani sebagai pribadi

b. Petani sebagai kepala keluarga

c. Petani sebagai guru (tempat bertanya bagi petani lain)

d. Petani sebagai pengelola usahatani

e. Petani sebagai warga sosial, kelompok

f. Petani sebagai warga Negara

3. Modal

Terdapat beberapa contoh modal dalam usahatani, misalnya: tanah, bangunan, alat-alat pertanian, tanaman, ternak, piutang dari bank dan uang tunai. Modal petani yang dimilik petani adalah berupa tanah dan tenaga kerja yang menunjang dalam proses pertanian.

4. Manajemen

Pengelolaan usahatani adalah kemampuan petani dalam merencanakan, mengorganisir, mengarahkan, mengkoordinasikan dan mengawasi faktor produksi yang dikuasai/dimiliknya sehingga mampu memberikan produksi seperti yang diharapkan. 
5. Faktor-faktor yang mempengaruhi keberhasilan usaha tani

Terdapat dua faktor yang mempengaruhi keberhasilan usahatani, yaitu:

1. Faktor intern

1) Petani pengelola

2) Tanah

3) Modal

4) Tenaga kerja

5) Teknologi

6) Jumlah keluarga

7) Kemampuan petani dalam mengalokasikan penerimaan keluarga

2. Faktor ekstern

1) Tersedianya sarana transportasi dan komunikasi

2) Aspek yang menyangkut pemasaran hasil dan bahan usahatani (harga hasil dan harga saprodi)

3) Fasilitas kredit

4) Sarana penyuluhan bagi petani.

\section{Rumusan Masalah}

Berdasarkan latar belakang maka perumusan masalah adalah belum di ketahuinya Karakteristik Petani Berlahan Sempit di Desa Tolok, Kecamatan Tompaso.

\section{Tujuan Penelitian}

Tujuan penelitian ini untuk mengetahui Karakteristik Petani Berlahan Sempit di Desa Tolok Kecamatan Tompaso.

\section{Manfaat Penelitian}

1. Bagi peneliti dapat melatih cara berpikir serta menganalisis data, dan penelitian ini merupakan salah satu syarat untuk memperoleh gelar sarjana di fakultas pertanian universitas sam ratulangi manado

2. Bagi pihak lain, penelitian ini diharapkan dapat menjadi referensi dan dapat menjadi tambahan informasi serta bahan pertimbangan dalam bidang penelitian.

\section{METODE PENELITIAN}

\section{Waktu Dan Tempat Penelitian}

Penelitian ini dilakukan selama dua bulan yaitu dari bulan Agustus sampai dengan bulan September 2019 mulai dari persiapan sampai penyusunan laporan penelitian, Penelitian ini bertempat di Desa Tolok, Kecamatan Tompaso.

\section{Metode Pengumpulan Data}

Metode pengumpulan data yang digunakan adalah wawancara dan observasi. Wawancara dilakukan pada petani langsung yang menjadi sampel penelitian dengan menggunakan pertanyaan (kuesioner). Observasi metode pengumpulan data dengan mengamati secara langsung dilapangan.

\section{Metode Pengambilan Sampel}

Pengambilan sampel dalam penelitian ini menggunakan metode Purposive Sampling. Jumlah petani responden sebanyak 33 petani yang memiliki lahan sempit yang mempunyai lahan kurang dari 0,5 hektar yang ada di Desa Tolok Kecamatan Tompaso.

\section{Konsep Pengukuran Variabel}

Variabel yang diukur dalam penelitian ini yaitu 1. Karakteristik petani :
1) Nama
2) Umur
3) Pendidikan terakhir
4) Tanggungan keluarga
5) Pengalaman bertani (tahun)
6) Pekerjaan sampingan

2. Karakteristik Usahatani
1) Luas pemilikan
2) Jenis tanaman
3) Pola tanam
4) Status pemilikan
5) Produksi
6) Penggunaan biaya produksi
7) Penggunaan Tenaga Kerja
8) Penerimaan
9) Pendapatan
10) Kegiatan off-farm dan non-farm
11) Produksi (Untuk Konsep Padi sawah)

\section{Metode analisis data}

Analisis yang digunakan dalam penelitian ini adalah analisis deskripsi, yaitu mendeskripsikan karakteristik petani berlahan sempit dan disajikan dalam bentuk tabel.

\section{HASIL DAN PEMBAHASAN}

\section{Deskripsi Lokasi Penelitian}

Desa Tolok adalah sebuah desa yang terletak di wilayah Kecamatan Tompaso, Kabupaten Minahasa, Provinsi Sulawesi Utara. Desa Tolok memiliki luas desa 1,48 $\mathrm{km}^{2}$ dengan ketinggian 802 $\mathrm{m}$ diatas permukaan laut. Jumlah penduduk desa tolok 716 orang yang terdiri dari 351 perempuan dan 365 lakilaki dan $208 \mathrm{KK}$ yang menghuni 3 (tiga) jaga yaitu jaga I, Jaga II, dan Jaga III. 
Jenis pekerjaan penduduk desa tolok yaitu petani, wiraswasta, swasta, PNS, tukang, supir, honorer dan mengurus rumah tangga. Tetapi, sebagian besar jenis pekerjaan penduduk yang ada di desa tolok yaitu sebagai petani. Areal usaha masyarakat petani terdiri dari lahan pertanian, sawah, dan tegalan. Jenis Tanaman yang dibudayakan dalam usaha tani masyarakat desa tolok antara lain umumnya Jagung, Padi, kacang tanah, dan tomat.

\section{Karakteristik Responden}

\section{Umur Responden}

Tingkat umur merupakan salah satu faktor yang mempengaruhi kemampuan seseorang dalam melakukan aktivitas maupun konsep berpikir. Responden yang berumur muda tentunya memiliki kondisi fisik lebih kuat dibandingkan dengan responden yang berumur tua. Secara umum dapat dikatakan bahwa makin tinggi umur maka makin berkurang kemampuan berprestasi sebagai tenaga kerja. Umur responden dalam penelitian ini disajikan pada Tabel 3.

Tabel 3. Jumlah Responden menurut Umur

\begin{tabular}{cccc}
\hline No. & $\begin{array}{c}\text { Umur } \\
\text { (Tahun) }\end{array}$ & $\begin{array}{c}\text { Jumlah } \\
\text { Responden } \\
\text { (orang) }\end{array}$ & Persentase (\%) \\
\hline 1. & $<45$ tahun & 6 & 18,18 \\
2. & $45-55$ tahun & 10 & 30,30 \\
3. & $>55$ tahun & 17 & 51,52 \\
\hline & Jumlah & $\mathbf{3 3}$ & $\mathbf{1 0 0}$ \\
\hline
\end{tabular}

Sumber : Data Primer diolah, 2019

Tabel 3 menunjukkan bahwa total jumlah responden petani yang memiliki lahan sempit sebanyak 33 orang, dengan mayoritas umur petani berkisar pada umur lebih dari 55 tahun pada persentase 51,52 (\%).

\section{Pendidikan Responden}

Tingkat pendidikan yang dimiliki petani akan menunjukkan tingkat pengetahuan serta wawasan yang luas untuk petani menerapkan apa yang diperolehnya untuk peningkatan usaha taninya. Tingkat pendidikan petani dimana petani yang berpendidikan tinggi relatif lebih cepat dalam melaksanakan adopsi inovasi. Tingkat pendidikan responden dapat dilihat pada Tabel 4.
Tabel 4. Tingkat Pendidikan Responden

\begin{tabular}{cccc}
\hline No. & $\begin{array}{c}\text { Tingkat } \\
\text { Pendidikan }\end{array}$ & $\begin{array}{c}\text { Jumlah } \\
\text { Responden } \\
\text { (orang) }\end{array}$ & $\begin{array}{c}\text { Persentase } \\
(\boldsymbol{\%})\end{array}$ \\
\hline 1 & SD & 9 & 27,27 \\
2 & SMP & 12 & 36,36 \\
3 & SMA & 10 & 30,30 \\
4 & Perguruan & 2 & 6,06 \\
\hline & Tinggi & $\mathbf{3 3}$ & $\mathbf{1 0 0}$ \\
\hline
\end{tabular}

Sumber : Data Primer diolah, 2019

Tabel 4 menunjukkan bahwa tingkat pendidikan yang dimiliki responden yang paling banyak yaitu tingkat SMP sebanyak 36,36 persen responden, tingkat SMA sebanyak 30,30 persen, tingkat SD 27,27 persen, dan tingkat perguruan tinggi sebanyak 6,06 persen.

\section{Jumlah Tanggungan}

Jumlah tanggungan keluarga yang dimaksud adalah banyaknya orang yang menjadi anggota dalam sebuah keluarga (rumah tangga). Sejalan dengan kebutuhan manusia, dapat dipahami bahwa semakin banyak anggota sebuah keluarga akan semakin besar pula kebutuhan yang akan dipenuhi, jumlah tanggungan keluarga dapat dilihat pada Tabel 5.

Tabel 5. Jumlah Tanggungan Keluarga Responden

\begin{tabular}{cccc}
\hline No. & $\begin{array}{c}\text { Tanggungan } \\
\text { (Jiwa) }\end{array}$ & $\begin{array}{c}\text { Jumlah } \\
\text { Responden } \\
\text { (orang) }\end{array}$ & Persentase (\%) \\
\hline 1. & $1-3$ & 28 & 84,85 \\
2. & 4 & 4 & 12,12 \\
3. & 5 & 1 & 3,03 \\
\hline \multicolumn{4}{r}{ Sumber : Data Primer diolah, 2019 }
\end{tabular}

Tabel 5 menunjukkan bahwa jumlah tanggungan keluarga yang paling banyak adalah antara 1-3 tanggungan sebanyak 84,85 persen , tanggungan keluarga sebanyak 4 tanggungan 12,12 persen dan tanggungan 5 orang 3,03 persen keluarga.

\section{Pengalaman Bertani}

Pengalaman bertani yaitu lamanya petani dalam melakukan kegiatan usaha tani. Pengalaman usaha tani adalah jumlah tahun berupa pengalaman yang dilalui petani lahan sempit sebagai bagian dari proses belajar dalam kegiatan budidaya, produksi dan seluk beluk usaha dan pemasaran hasil panen dalam rangka memperoleh penghasilan. Pengalaman bertani dapat dilihat pada Tabel 6. 
Tabel 6. Pengalaman Bertani

\begin{tabular}{cccr}
\hline No. & $\begin{array}{c}\text { Pengalaman } \\
\text { (tahun) }\end{array}$ & $\begin{array}{c}\text { Jumlah } \\
\text { Responden } \\
\text { (orang) }\end{array}$ & Persentase (\%) \\
\hline 1. & $1-20$ & 12 & 36,36 \\
2. & $21-40$ & 15 & 45,45 \\
3. & $41-60$ & 6 & 18,18 \\
\hline & Jumlah & $\mathbf{3 3}$ & $\mathbf{1 0 0}$ \\
\hline
\end{tabular}

Sumber : Data Primer diolah, 2019

Tabel 6 menunjukkan bahwa pada penelitian ini mayoritas petani $(45,45 \%)$ memiliki pengalaman usaha tani antara 21 tahun sampai dengan 40 tahun. Rata-rata pengalaman petani berusahatani adalah 35 tahun.

\section{Karakteristik Usahatani}

\section{Luas Lahan}

Luas lahan responden adalah areal lahan yang diusahakan oleh petani yang dinyatakan dalam hektar (ha). Luas penguasaan lahan pertanian merupakan sesuatu yang sangat penting dalam proses produksi ataupun usaha tani, luas lahan akan mempengaruhi besarnya produksi yang diusahakan dan kesejahteraan yang akan mereka peroleh. Luas lahan dapat dilihat pada Tabel 7.

\section{Tabel 7. Luas Lahan Responden}

\begin{tabular}{cccr}
\hline No. & Luas Lahan (ha) & $\begin{array}{c}\text { Jumlah } \\
\text { Responden }\end{array}$ & Persentase (\%) \\
\hline 1. & 0,07 & 2 & 6,06 \\
2. & 0,105 & 2 & 6,06 \\
3. & 0,14 & 5 & 15,15 \\
4. & 0,175 & 24 & 72,73 \\
\hline & Jumlah & $\mathbf{3 3}$ & $\mathbf{1 0 0}$ \\
\hline
\end{tabular}

Sumber : Data Primer diolah, 2019

Tabel 7 menunjukkan bahwa dari 33 responden dalam penelitian ini lebih banyak petani lahan sempit memiliki luas lahan 0,175 hektar atau 1750 meter persegi. Selebihnya petani memiliki luas lahan $<0,175$ hektar yaitu 0,07 atau 700 meter persegi, luas lahan 0,105 atau 1050 meter persegi dan 0,14 atau 1400 meter persegi.

\section{Jenis Tanaman}

Jenis tanaman yaitu komoditi yang di budidayakan oleh petani untuk di panen pada masa ketika sudah mencapai tahap pertumbuhan tertentu. Jenis tanaman yang dibudidayakan juga melalui proses pengalaman dengan mempertimbangkan hemat tenaga, waktu, dan biaya perawatan. Jenis tanaman dapat dilihat pada Tabel 8.
Tabel 8. Jenis Tanaman

\begin{tabular}{|c|c|c|c|c|}
\hline No. & $\begin{array}{c}\text { Jenis } \\
\text { Tanaman }\end{array}$ & $\begin{array}{c}\text { Luas } \\
\text { Lahan } \\
\text { (ha) }\end{array}$ & $\begin{array}{c}\text { Jumlah } \\
\text { Responden }\end{array}$ & Persentase $(\%)$ \\
\hline \multirow[t]{3}{*}{1} & Jagung & 0,105 & 2 & 6,06 \\
\hline & & 0,14 & 2 & 6,06 \\
\hline & & 0,175 & 12 & 36,36 \\
\hline \multirow[t]{3}{*}{2} & Padi & 0,07 & 2 & 6,06 \\
\hline & & 0,14 & 3 & 9,09 \\
\hline & & 0,175 & 5 & 15,15 \\
\hline 3 & $\begin{array}{l}\text { Kacang } \\
\text { tanah }\end{array}$ & 0,175 & 5 & 15,15 \\
\hline \multirow[t]{2}{*}{4} & Tomat & 0,175 & 2 & 6,06 \\
\hline & \multicolumn{2}{|c|}{ Jumlah } & 33 & 100 \\
\hline
\end{tabular}

Sumber : Data Primer diolah, 2019

Tabel 8 menunjukkan bahwa penguasaan lahan pada penelitian ini petani lebih banyak mengusahakan tanaman jagung. Penguasaan Tanaman jagung dengan luas lahan 0,105 hektar dengan persentase 3,03 persen, luas lahan 0,14 hektar dengan 3,03 persen dan luas lahan 0,175 hektar dengan 36,36 persen mengusahakan jenis tanaman jagung. Jenis tanaman padi dengan luas lahan 0,07 hektar memiliki persentase 6,06 persen, luas lahan 0,14 dengan 9,09 persen dan luas lahan 0,175 dengan pesentase 15,15 persen mengusaha-kan jenis.

\section{Pola Tanam}

Pola tanam yaitu usaha penanaman pada sebidang lahan dengan mengatur susunan tata letak dan urutan tanaman selama periode waktu tertentu. Pola tanam terbagi menjadi dua jenis, yaitu pola tanam monokultur dan pola tanam polikulutur. Pola tanam monokultur adalah sistem pola tanam atau cara budidaya pada suatu lahan pertanian dengan menanam satu jenis tanaman dalam waktu satu tahun sedangkan pola tanam polikultur adalah sistem pola tanam dalam pertanian dengan menanam lebih dari satu jenis tanaman pada satu bidang lahan yang sama. Pola tanam polikultur terbagi menjadi beberapa jenis yaitu tanam bergiliran dan tanam tumpangsari. Pola tanam dapat dilihat pada Tabel 9.

Tabel 9. Pola Tanam

\begin{tabular}{lcccc}
\hline No. & Pola Tanam & $\begin{array}{c}\text { Jumlah } \\
\text { Responden } \\
\text { (orang) }\end{array}$ & $\begin{array}{c}\text { Jenis } \\
\text { Tanaman }\end{array}$ & $\begin{array}{c}\text { Persentase } \\
(\mathbf{\%})\end{array}$ \\
\hline 1. & Monokultur & 10 & Padi & 36,36 \\
2. & Polikultur & 16 & Jagung & 48,48 \\
& & 5 & Kacang & 15,15 \\
& & 2 & Tanah & 6,06 \\
\hline & Jumlah & $\mathbf{3 3}$ & & $\mathbf{1 0 0}$ \\
\hline
\end{tabular}

Sumber : Data Primer diolah, 2019 
Tabel 9 menunjukkan bahwa pola tanam polikultur paling banyak di usahakan petani, mayoritas petani dalam penelitian ini menanam secara bergiliran dengan jenis tanaman yang di usahakan yaitu jagung dengan memiliki persentase $48,48 \%$, kacang tanah $15,15 \%$, dan tomat $6,06 \%$. Sedangkan, pola tanam monokultur memiliki persentase 36,36 persen dengan jenis tanaman yang di usahakan petani yaitu tanaman padi.

\section{Produksi}

Produksi adalah suatu proses mengubah bahan baku menjadi barang jadi atau menambah nilai suatu produk agar dapat memenuhi kebutuhan rata-rata produksi, rata-rata penerimaan dan rata-rata pendapatan dalam penelitian ini yang diambil dari 33 responden yang memiiki lahan sempit. Produksi, penerimaan dan pendapatan yang di dapat dari setiap petani yang memiliki lahan sempit tidaklah selalu sama, produksi yang dihasilkan dapat berubah dipengaruhi oleh beberapa faktor seperti cuaca, hama dan penyakit. Produksi, penerimaan dan pendapatan dapat dilihat Tabel 10.

Tabel 10. Produksi, Penerimaan dan Pendapatan

\begin{tabular}{|c|c|c|c|c|c|c|}
\hline No. & $\begin{array}{c}\text { Jenis } \\
\text { Tanaman }\end{array}$ & $\begin{array}{c}\text { Luas } \\
\text { lahan } \\
(\text { Ha) }\end{array}$ & $\begin{array}{l}\text { Harga/ } \\
\text { Kg (Rp) }\end{array}$ & $\begin{array}{l}\text { Rata-rata } \\
\text { Produksi } \\
(\mathbf{K g})\end{array}$ & $\begin{array}{c}\text { Rata-rata } \\
\text { Penerimaan } \\
(\mathbf{R p})\end{array}$ & $\begin{array}{c}\text { Rata-rata } \\
\text { Pendapatan } \\
\text { (Rp) }\end{array}$ \\
\hline \multirow{3}{*}{1.} & Jagung & 0,105 & 4.000 & 223 & 890.000 & 440.000 \\
\hline & & 0,14 & 4.000 & 262 & $1,050.000$ & 450.000 \\
\hline & & 0,175 & 4.000 & 372 & $1,488.625$ & 930.923 \\
\hline \multirow{3}{*}{2.} & & 0,07 & 10.000 & 155 & 890.000 & 440.000 \\
\hline & Padi & 0,14 & 10.000 & 296 & $2,956.667$ & $1,956.667$ \\
\hline & & 0,175 & 10.000 & 375 & $3,752.000$ & $1,972.000$ \\
\hline 3. & $\begin{array}{l}\text { Kacang } \\
\text { Tanah }\end{array}$ & 0,175 & 10.000 & 152 & $1,520.000$ & $1,007.500$ \\
\hline 4. & Tomat & 0,175 & 12.000 & 1,008 & $12,090.000$ & $7,090.000$ \\
\hline
\end{tabular}

Tabel 10 menunjukkan pendapatan jenis tanaman tomat yang paling menguntungkan, tetapi petani pada penelitian ini paling banyak mengusahakan tanaman jagung karena biaya yang dikeluarkan tidak banyak dibandingkan jenis tanaman lain,dan sebagian hasil produksi sebagai makanan ternak.

\section{Penggunaan biaya Produksi}

Biaya produksi adalah akumulasi dari semua biaya-biaya yang dibutuhkan dalam proses produksi dengan tujuan untuk menghasilkan suatu produk atau barang. Biaya digunakan dalam proses produksi, biaya tetap dan biaya variabel. Biaya produksi adalah biaya yang dikeluarkan untuk memperoleh hasil yang sudah diterima. Penggunaan biaya produksi dapat dilihat Tabel 11.
Tabel 11. Biaya Produksi

\begin{tabular}{ccrr}
\hline \multirow{2}{*}{ No. } & $\begin{array}{c}\text { Jenis } \\
\text { Tanaman }\end{array}$ & $\begin{array}{r}\text { Luas lahan } \\
(\mathbf{H a})\end{array}$ & $\begin{array}{c}\text { Rata-rata } \\
\text { Biaya Produksi (Rp) }\end{array}$ \\
\hline \multirow{2}{*}{ 1. } & \multirow{2}{*}{ Jagung } & 0,105 & 450.000 \\
& & 0,14 & 600.000 \\
& & 0,175 & 557.692 \\
2. & Padi & 0,07 & 600.000 \\
& & 0,14 & 1.000 .000 \\
3. & Kacang Tanah & 0,175 & 1.780 .000 \\
4. & Tomat & 0,175 & 512.500 \\
\multicolumn{2}{l}{ Sumber $:$ Data Primer diolah, 2019} & 5.000 .000 \\
\hline
\end{tabular}

Tabel 11 menunjukkan penggunaan biaya produksi pada penelitian ini yang didalamnya terdapat jenis biaya tetap dan biaya variabel. Biaya tetap adalah biaya yang jumlah totalnya akan sama dan tetap tidak berubah, dalam penelitian ini biaya tetap yaitu alat-alat pertanian. Biaya variabel adalah biaya yang berubah ubah menurut tinggi rendahnya tingkat pengeluaran. Biaya variabel dalam penelitian ini yaitu biaya benih, biaya pupuk, biaya pestisida dan biaya tenaga kerja.

\section{Kegiatan Off-Farm dan Non-farm}

Off-farm activities adalah semua pekerjaan yang dikerjakan di luar usaha tani sendiri untuk mengatasi pengangguran musiman. Non-farm activities adalah semua kegiatan non pertanian yang mendatangkan penghasilan bagi rumah tangga, di dalamnya tidak termasuk kegiatan di usaha tani sendiri maupun berburuh pada usaha tani orang lain. Kegiatan Off-Farm dan Non-farm dapat dilihat pada Tabel 12.

\begin{tabular}{|c|c|c|c|}
\hline \multirow{2}{*}{ No. } & \multicolumn{2}{|c|}{ Kegiatan } & \multirow{2}{*}{$\begin{array}{c}\text { Rata-rata } \\
\text { Pendapatan }\end{array}$} \\
\hline & Off-farm & Non-farm & \\
\hline 1. & Buruh & & Rp. 100.000/hari \\
\hline 2. & & $\begin{array}{l}\text { Buruh } \\
\text { bangunan }\end{array}$ & Rp. $125.000 /$ hari \\
\hline 3. & & $\begin{array}{l}\text { Tukang } \\
\text { Ojek }\end{array}$ & Rp. $100.000 /$ hari \\
\hline 4. & & $\begin{array}{l}\text { Kusir } \\
\text { Delman }\end{array}$ & Rp. 75.000/hari \\
\hline 5. & & Wirausaha & Rp. $800.000 /$ hari \\
\hline
\end{tabular}

Tabel 12 menunjukkan kegiatan yang di lakukan petani dalam penelitian ini untuk mendatangkan penghasilan bagi rumah tangga petani di luar pekerjaan pokok. Pendapatan offfarm meliputi pendapatan yang berasal dari 
kegiatan buruh harian tani, selain itu sebagian petani juga beternak. Kegiatan buruh harian tani tidak setiap hari di lakukan kegiatan ini seringkali hanya dua sampai tiga kali dalam satu minggu. Beternak juga di lakukan petani untuk mendatangkan penghasilan yaitu ternak ayam, ternak babi, ternak bebek dan ternak sapi.

Pendapatan non-farm meliputi jasa sebagai buruh bangunan, tukang ojek, kusir delman dan berdagang. Buruh bangunan di kerjakan petani untuk mendatangkan penghasilan rumah tangga petani yang di biayai Rp.125.000/harinya, buruh bangunan di kerjakan di luar pekerjaan pokok karena pekerjaan ini tidak setiap hari di kerjakan petani. Selain buruh bangunan menjadi tukang ojek dikerjakan petani berlahan sempit dengan penghasilan satu hari ratarata Rp. 100.000 - Rp.150.000/hari jasa ojek seringkali di pakai atau di sewa dengan biaya Rp. 20.000 - Rp. 50.000 tergantung jarak dan waktu yang di tentukan. Kusir delman juga di kerjakan petani dan pendapatan yang di terima tidak selalu sama, kusir delman hanya tiga kali dalam satu minggu di kerjakan. Sedangkan Wirausaha yang di lakukan dalam memenuhi kebutuhan petani meliputi usaha warung atau kios sembako.

\section{Kesejahteraan Petani}

Prinsipnya kesejahteraan berkaitan erat dengan kebutuhan dasar. Kebutuhan dasar tersebut berupa kecukupan dan mutu pangan, sandang, papan, kesehatan, pendidikan, lapangan pekerjaan, dan kebutuhan dasar lainnya.

Kebutuhan rumah tangga petani yang memiliki lahan sempit dalam memenuhi kebutuhan sehari-hari (pangan) petani mengeluarkan biaya rata-rata Rp. $75.000-\mathrm{Rp}$. 100.000/hari, tetapi bahan seperti cabai, bawang merah, daun bawang bisa di gunakan selama 2-3 hari, sehingga biaya untuk pangan di hari berikunya berkurang. Anak petani dalam penelitian ini yang sudah menyelesaikan pendidikan namun masih terhitung dalam tanggungan keluarga membantu keluarga dalam memenuhi kebutuhan hidup. Ibu Rumah tangga dalam penelitian ini juga ikut membantu keluarga petani dalam memenuhi kebutuhan rumah tangga sesuai dengan keahlian dan kemampuan.
Pekerjaan dan pendapatan di sektor pertanian pada umumnya bersifat musiman, sehigga diperlukan waktu tunggu yang relatif lama sebelum pendapatan dinikmati. Dengan situasi demikian peranan pekerjaan yang memberikan pendapatan di luar usaha tani amat penting. Pekerjaan lain di lakukan petani berlahan sempit tergantung keahlian dari setiap petani untuk mendatangkan penghasilan dalam memenuhi kebutuhan rumah tangga dan untuk kelangsungan hidup. Aktivitas usaha di luar usaha tani tersebut dapat memberikan sumbangan bagi keluarga petani, sehingga dapat memenuhi kebutuhan hidup, karena jika hanya mengharapkan hasil produksi dari lahan pertanian yang luasnya hanya 1750 meter persegi ke bawah atau 0,175 ha tidak akan cukup untuk memenuhi kebutuhan hidup keluarga petani. Dalam penelitian ini kebutuhan petani masih bisa dapat terpenuhi karena usaha dari petani untuk memenuhi setiap kebutuhan, Ratarata petani dalam penelitian ini tidak sepenuhnya menggantungkan diri pada hasil pertanian.

\section{KESIMPULAN DAN SARAN}

\section{Kesimpulan}

Berdasarkan hasil penelitian di lapangan, dapat disimpulkan bahwa petani yang memiliki lahan sempit dengan pendapatan yang rendah tidak mampu hanya mengandalkan sektor pertanian sebagai sumber pendapatan. Sektor non pertanian juga dijadikan sumber pendapatan tambahan untuk memenuhi kebutuhan.

Pendapatan dari usaha tani tidak mencukupi untuk memenuhi kebutuhan hidup dengan mengusahakan lahan yang sempit $(0,175$ ha). Melakukan aktivitas di luar usaha tani adalah mudahnya mengembangkan usaha di luar pertanian, pendapatan yang diperoleh lebih tinggi, tidak tergantung musim dan waktunya bebas.

\section{Saran}

1. Bagi petani yang masih memiliki lahan kurang dari 0,175 ha atau 1750 meter $^{2}$, sebaiknya memanfaatkan lahan tidur yang tidak digunakan dengan cara sewa atau bagi hasil dengan pemilik lahan, untuk menambah pendapatan. 
2. Sebaiknya petani menyempatkan diri dalam mengikuti kegiatan penyuluhan yang diadakan untuk menambah pengetahuan supaya dapat menambah hasil produksi.

3. Untuk meningkatkan pendapatan, petani harus melakukan kegiatan di luar bertani yang mampu menambah pendapatan.

\section{DAFTAR PUSTAKA}

Hasyim, H. 2003. Analisis Hubungan Faktor Sosial Ekonomi Petani Terhadap Program Penyuluhan Pertanian. Laporan Hasil Penelitian. Universitas Sumatera Utara. Medan.

Joachim Von Braun, M. S., \& Rosegrant, M. W. 2004. Agriculture, food security, nutrition and the Millennium Development Goals. Intl Food Policy Res Inst.
Rahim, A., \& Hastuti, D. R. D. 2007. Ekonomika Pertanian (Pengantar, Teori, dan Kasus). Penerbit Penebar Swadaya. Cimanggis, Depok, Jakarta.

Sajogyo, 1977. Golongan miskin dan partisipasi dalam pembangunan Desa. dalam Prisma, 6 (3) Tahun Maret. LP3S, Jakarta.

Soekartawi. 2003. Agribisnis Teori dan Aplikasinya. Jakarta: PT. Raja Grafindo Persada. 